\title{
Evaluation of Injury/Illness Recordkeeping Pilot Course Taught in Richland, Washington January 15, 1992
}

T. S. Wright

March 1992

Prepared for the U.S. Department of Energy under Contract DE-AC06-76RLO 1830

Pacific Northwest Laboratory

Operated for the U.S. Department of Energy

by Battelle Memorial Institute 


\title{
DISCLAIMER
}

This report was prepared as an account of work sponsored by an agency of the United States Government. Neither the United States Government nor any agency thereof, nor Battelle Memorial Institute, nor any of their employees, makes any warranty, expressed or implied, or assumes any legal liability or responsibility for the accuracy, completeness, or usefulness of any information, apparatus, product, or process disclosed, or represents that its use would not infringe privately owned rights. Reference herein to any specific commercial product, process, or service by trade name, trademark, manufacturer, or otherwise does not necessarily constitute or imply its endorsement, recommendation, or favoring by the United States Government or any agency thereof, or Battelle Memorial Institute. The views and opinions of authors expressed herein do not necessarily state or reflect those of the United States Government or any agency thereof.

\author{
PACIFIC NORTHWEST LABORATORY \\ operated by \\ BATTELLE MEMORIAL INSTITUTE \\ for the \\ UNITED STATES DEPARTMEINT OF ENERGY \\ under Contract DE-AC06-76RLO 1830
}

Printed in the United States of America

Available to DOE and DOE contractors from the

Office of Scientific and Technical Information, P.O. Box 62, Oak Ridge, IN 37831; prices available from (615) 576-8401. FTS 626-8401.

Available to the pubiic from the National Technical Information Service, U.S. Department of Commerce, 5285 Port Royal Rd., Springfield, VA 22161. 
PNL- -8034

DE92 010397

EVALUATION OF INJURY/ILLNESS

RECORDKEEPING PILOT COURSE TAUGHT IN

RICHLAND, WASHINGTON JANUARY 15, 1992

\section{T.S. Wright}

March 1992

Prepared for the U.S. Department of Energy

under Contract DE-ACO6-76RLO 1830

Pacific Northwest Laboratory

Richland, Washington 99352

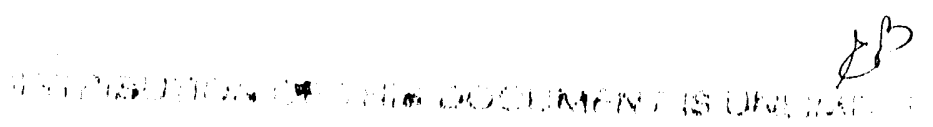




\section{CONTENTS}

1.0 SUMMARY--HANFORD (JANUARY $15,19 \Omega 2) \ldots \ldots \ldots$

1.1 SUMMARY OF TRAINEE COURSE EVALUATIONS AT HANFORD $\ldots \ldots \ldots$

1.2 NUMERIC RATINGS . . . . . . . . . . . . 1.2

1.3 WRITTEN COMMENTS . . . . . . . . . . . . . 1.5

1.4 EXAMINATION RESULTS . . . . . . . . . . . . . . 1.5

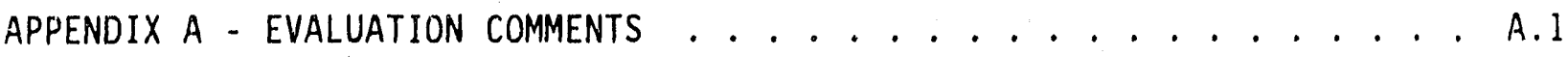
APPENDIX B - TRAINEE EVALUATION FORM .............. B.1 


\subsection{SUMAARY}

This section summarizes trainee evaluations for the Safety Training Section course, Injury/I11ness Recordkeeping which was conducted January 15, at Hanford, in Richland, Washington. This class was the first pilot course taught. This class was designed to acquaint attendees with DOE orders 5484.1, 5484.1A, draft 3 and the OSHA regulations found in 29 CFR 1904. This goal was partially achieved; the section pertaining to DOE orders must be improved prior to the next pilot class.

Section 1.1 and 1.2 of this report summarize the quantitative course evaluations that trainees provided upon completion of the course. Appendix $A$ provides a transcript of the trainees' written comments.

Numeric course ratings were generally positive and show that the course material and instruction were very effective. Written comments supported the positive numeric ratings. The course content and knowledge gained by the trainees exceeded most of the students' expectations of the course.

Results from the final examination showed that students gained significant knowledge from the course.

\subsection{SUMMARY OF TRAINEE COURSE EVALUATION AT HANFORD}

This course was conducted at Hanford, in Richland, Washington, January 15, 1992. Two instructors and a course administrator presented the course to twenty-one Westinghouse, Battelle PNL, Richland Field Office, and Hanford Environmental Health Foundation personnel. 


\subsection{NUMERIC RATINGS}

Twenty-one trainees completed a course evaluation form upon finishing the course. The first rating area of the form covered three items dealing with course content; the second rating area covered one item dealing with testing materials; and the third rating area covered ten items specifically associated with course topic areas.

For the first and second rating areas, respondents were instructed to rate the degree to which they agreed or disagreed with each statement using a five-point scale with 1 (low) anchored to "strongly disagree" and 5 (high) anchored to "strongly agree". The ratings are as follows:

\section{COURSE CONTENT AND TESTING MATERIALS RATINGS}

1. Developed specific skills and competencies in injury/illness recordkeeping.

Average Class Rating - $\underline{3.75}$

2. Gained a greater understanding of 29 CFR 1904.

Average Class Rating - $\underline{3.75}$

3. Would recommend this course to others.

Average Class Rating - $\underline{4.55}$

4. The final test was a good measure of the knowledge gained in the course.

Average Class Rating - $\underline{3.60}$

The average class rating for the course content area and testing materials area was 3.91 . This reinforces the applicability of the course content to the trainees' interests and work environments.

This rating also shows need for improvement. 'Several possibilities have been discussed as to content. The idea of including SPMS system information as well as vehicle and property damage has been posed to DOE. PNL's currently working with Janet Macon of EH-31.4 to better define the scope, duration, focus, target population, purpose and objective for this course. 
The third rating area asked the respondents to rate the value of each of the fifteen topic areas using a five-point scale with 1 (Unsatisfactory), 2 (Satisfactory), 3 (Good), 4 (Very Good), or 5 (Excellent). The following are the average class ratings that dealt with topic content as well as with the value of the instructor:

\begin{tabular}{||l|l||c|c||}
\hline $\begin{array}{l}\text { INSTRUCTOR } \\
\text { NAME }\end{array}$ & \multicolumn{1}{|c|}{ TOPICAL AREAS PRESENTED } & $\begin{array}{l}\text { CONTENT } \\
\text { RATING }\end{array}$ & $\begin{array}{l}\text { INSTRUCTOR } \\
\text { RATING }\end{array}$ \\
\hline L. Hubschman & DOE Order 5484.1 Chapter 1 & 2.60 & 2.55 \\
\hline L. Hubschman & DOE Order 5484.1A Draft 3 & 2.60 & 2.65 \\
\hline L. Ballas & Sample Forms & 3.55 & 3.90 \\
\hline L. Ballas & Penalties & 3.95 & 4.30 \\
\hline L. Ballas & 29 CFR 1904 & 3.50 & 3.95 \\
\hline L. Ballas & Exercise & 4.25 & 4.55 \\
\hline L. Ballas & OSHA Log & 4.40 & 4.60 \\
\hline L. Ballas & Medial Case Records & 3.95 & 4.20 \\
\hline
\end{tabular}

The overall average class rating for specific topic content was 3.60 . The overall average class ratings for the instructors were 2.6 for L. Hubschman and 4.25 for L. Ballas. Due to L. Hubschman's $10 w$ ratings and his strong desire not to be an instructor, a different person will be used for the next class. 


\subsection{WRITTEN COMMENTS}

After providing numeric course evaluations, participants provided written cominents about the course. Written comments were transcribed and are presented verbatim in Appendix A.

\subsection{EXAMINATION RESULTS}

On the last day of the course, a final examination was administered to eighteen attendees. There were 15 questions all questions were multiple choice. The scores ranged from $73.3 \%$ to $100 \%$ with the average score being $87.8 \%$. Eighteen persons successfully completed the course. 
APPENDIX A

EVALUATION COMMENTS

INJURY/ILLNESS RECORDKEEPING

JANUARY 15, 1992

RICHLAND, WA (HANFORD) 
APPENDIX A

TRAINEE EVALUATION RESPONSES

INJURY/ILLNESS RECORDKEEPING

JANUARY 15, 1992-RICHLAND, WA

HANFORD

Please briefly describe how your expectations of this course were or were not met.

They were met, except I would like to know more about required retention of logs and reports at other than at the establishment, which was covered.

I liked the course.

Need to see/hear DOE embracing what Linda said.

Being new to my job, this course helped considerably, my expectations were well met.

Instructor completely answered all questions.

This course was not as in depth as I had expected, but it did seem to present new information to a lot of the other attendees.

Good information was provided. The requirements were presented as being more clear and definite than they really are. The instructor contradicted prior statements on several occasions.

Coverage of the DOE orders was less than expected.

Clarification for my questions were answered in an excellent manner.

My expectations were met.

All factors that related to Injury/I1lness recordkeeping were answered.

Provided a fairly good basic understanding but there are complex issues that can only be learned/resolved with time and experience.

I now have a better understanding of the OSHA $200 \mathrm{log}$.

This subject requires practical experience and time for proficiency.

Expectations were exceeded. OSHA recordable materials and recordkeeping requirements were laid out well. 
The most helpful topics covered or activities presented in this course were:

All topics were helpful.

Al1 were helpful.

Recordkeeping requirements and posting.

The forms and how to fill them out.

How to iterate cause for recordable accidents and $i 11$ nesses.

Detailed examples of $\log$ entries.

Difference between an injury or iliness.

Handouts and exercises.

OSHA guidelines.

Clarifications of detailed recordkeeping requirements.

The blue book.

The entire course is very beneficial.

OSHA log exercise.

What was or was not recordable.

200 form compliance notes in blue book to refer to later.

Good exercise on OSHA $10 \mathrm{~g}$.

Student-instructor interaction.

Exercises.

The least helpful things discussed or done were:

All were helpful.

Any of the DOE discussion was less than helpful. I did not learn much of anything from that portion of the course.

DOE guidelines.

A11 information was relevant to me.

Too much time allowing people to ask "what if" questions.

Discussions of penalties and citations.

\section{A. 2}


DOE orders.

DOE order and 29 CFR 1904.

I feel that the portion of the presentations left a lot to be desired and was weighted to heavily on the test given the proportion of time spent of it.

The DOE topics were not well presented.

Discussion of actual injury/illness incidents.

More emphasis should be given to:

DOE requirements. Time for individual case discussion would have been good, but ability to ask questions throughout was nice.

DOE/BLS togetherness. I just don't see that Linda and DOE see this the same. For example CAIRS form.

DOE requirements.

Regulation requirements and correct procedure. Hands-on form usage.

Marginal/gray area recordability decision, and the fact that many of the "rights" and "wrongs" are judgement calls on the part of the auditor.

DOE order and 29 CFR 1904 if this information will assist the understanding of the OSHA-BLS information.

Less emphasis should be given to:

DOE orders are not pertinent unless they are updated and have requirements more stringent than OSHA's.

Penalties.

Penalties/citations (unless you can make it more DOE specific).

Rules and more rules-very confusing.

What specific suggestions do you have for improving future sessions?

DOE expectations explained in more detail.

Better introduction of speakers, did not understand where they were employed.

Improve gray areas arising from OSHA guidelines.

Get a different DOE presenter. 
Make sure what Linda says DOE agrees with.

Different coverage of the DOE material.

I thought this was just right as is.

Create the class to a two day. Especially if DOE orders are improved.

Some parts get a bit long, may want to break a little more often to keep up attentiveness.

Don't contradict yourself. Listen to the questions better. Acknowledge the gray area.

Make more hands on recordkeeping.

Several days may be needed to reinforce learning.

Compare DOE vs. OSHA requirements.

Other materials to supplement or substitute for the provided handouts? No answers.

Daily schedule/timing of activities, worktime?

Good.

Was timed/scheduled appropriately.

Class a little too long for 1 day, too rushed. Maybe cut down lunch time.

Not enough time given to mock OSHA log exercise.

Good.

Several days needed.

Facilities/training room arrangements?

Very good.

Great.

Good.

Excellent.

Fine as is. 
What other types of safety training courses would you like to see available? Lasar, EMF.

Site specific hazard recognition for supervisor manager and employees. Also all safety professional need to attend training in all areas where new or revised rules and laws have changed.

OSHA inspector course. To see what will be looked at.

Any further comments?

Employee responsibilities for reporting injuries should be emphasized more.

Instructor did a good job, please ask some people to limit questions/comments. This slowed the course down too much.

The instructor was excellent. Extremely knowledgeable in this area.

Linda is an excellent instructor. Her expertise is obvious and appreciated. She remained patient during repeated rephrasing of the same question. Keep her.

I think the DOE folks should attend to find out what the deficiencies are in their system. 
APPENDIX B

TRAINEE EVALUATION FORM 
EVALUATION FORM

Date Injury/llIness Recordkeeping

Name

Title

Location Hanford

Please list your major job duties.

What do you expect to gain from this course?

Briefly describe your safety training within the last three years.

Please evaluate various features of the course you have just completed. Your comments will be kept confidential. The information you provide here will be combined with that from other attendees and summarized for the sponsor, the U.S. Department of Energy. Results from this evaluation will be used to improve this course.

\section{Course Content}

Strongly

Overall, as a result of this course I believe that I:

developed specific skills and competencies in

Injuryfllness recordkeeping.

. .5

gained a greater understanding of 29 CFR 1904 .

would recommend this course to others. 5

.5

4

Neither Agree

nor Disagree Disagree

Strongly

Agree Agree

Disagree

\section{Testing Materials}

The final test was a good measure of the

knowledge gained in the course. . .5

4

3

2

1

3

2

1

\section{Topic Areas}

Please evaluate each topic area using the 5-point scale below.
5 Excellent
4 Very Good
3 Good
2 Satisfactory 1 Unsatisfactory

DOE Order 5484.1 Chapter 1

Content

DOE Order 5484.1A Draft 3

4321

Sample Forms 5

Penalties $\begin{array}{llll}4 & 3 & 2 & 1\end{array}$

$\begin{array}{llll}4 & 3 & 2 & 1\end{array}$

29 CFR 1904

$\begin{array}{llll}4 & 3 & 2 & 1\end{array}$

Exercise $\begin{array}{llll}4 & 3 & 2 & 1\end{array}$

OSHA LOg $\begin{array}{llll}4 & 3 & 2 & 1\end{array}$

Medical Case Records
Instructor

$\begin{array}{lllll}5 & 4 & 3 & 2 & 1\end{array}$

$\begin{array}{lllll}5 & 4 & 3 & 2 & 1\end{array}$

$\begin{array}{lllll}5 & 4 & 3 & 2 & 1\end{array}$

$\begin{array}{lllll}5 & 4 & 3 & 2 & 1\end{array}$

$\begin{array}{lllll}5 & 4 & 3 & 2 & 1\end{array}$

$\begin{array}{lllll}5 & 4 & 3 & 2 & 1\end{array}$

$\begin{array}{lllll}5 & 4 & 3 & 2 & 1\end{array}$

$\begin{array}{lllll}5 & 4 & 3 & 2 & 1\end{array}$ 
1. Please briefly describe how your expectations of this course were or were not met.

2. The most helpful topics covered or activities presented in this course were:

3. The least helptul toples or activities in this course were:

4. More emphasis should be given to:

5. Less emphasis should be given to:

6. What specific suggestions do you have for improving future sessions?

7. Other materials to supplement or substitute for the provided handouts?

8. Daily schedule/timing of activities, worktime?

9. Facilities/training room arrangements?

10. What other types of safety training courses would you like to see available?

11. Any further comments?

12. Overall rating:

Based on your comments above, please rate the course on a 5-point scale by drcling the number of your choice.
5 Excellent
4 Very Good
3 Good
2 Satisfactory
1 Unsatisfactory

B. 2 


\section{DISTRIBUTION}

No. of

Copies

OFFSITE

12 DOE/Office of Scientific and Technical Information

R. E. Gibbs

Office of Safety and Quality Programs

U.S. Department of Energy

19901 Germantown Rd.

Germantown, MD 20874

G. R. Florczak

U.S. Department of Energy

19901 Germantown Rd.

Germantown, MD 20874

L. Ballas

5 South Andover Ln.

Geneva, IL 60134-1873

D. T. Evans

DOE Richland Field office

P.0. Box 550

Richland, WA 99352
No. of

Copies

ONSITE

DOE Richland Field Office

P. W. Kruger

8 Pacific Northwest Laboratory

H. N. Bowers

T. S. Wright

Publishing Coordination

Technical Report Files (5) 

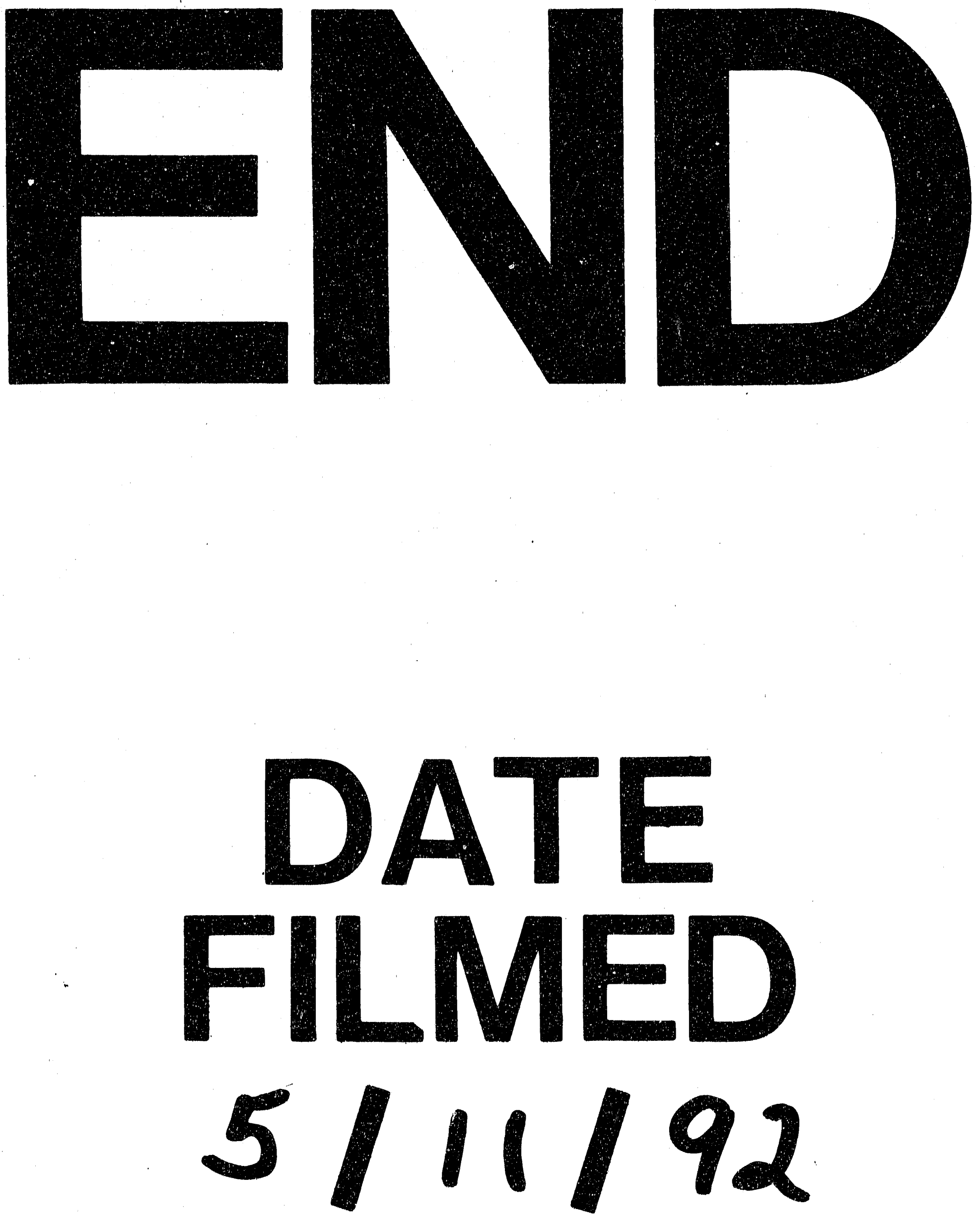
